\title{
The Concept of Dilthey's Hermeneutics as Reflected in Juliasih's Potensi Perempuan Amerika (Tinjauan Feminisme)
}

\author{
M. Afifulloh \\ English Departmen, University of Bangka Belitung \\ E-mail: afifulloh@mail.ugm.ac.id
}

\begin{abstract}
This paper aims at the description of Dilthey's hermeneutics concept in the book entitled "Potensi Perempuan Amerika (tinjauan feminisme)". This research is qualtative descriptive research. The data were analyzed by Dilthey's hermeneutic approach. The result showed that in understanding and interpreting meaning, there are 3 formulas that can be used as interpretive methods, namely Erlebnis (living experience), Ausdruck (expression), and Verstehen (understanding). The experience referred to here is the life history of the author, everything that was experienced by the director during his lifetime. The expressions are works written by the author through the language used to voice their desires, opinions and actions. Understanding is the process of bringing together all the data generated from the process of experience and expression so that it can draw conclusions. In the research conducted by Juliasih Kusharyanto, it can be concluded that the three main aspects of the hermeneutics have been carried out well so that in the end the results of the research are able to provide a complete meaning from the historical side as well as language expressions that exist in the storyline of each novel studied.
\end{abstract}

Keywords: Wilhelm Dilthey, hermeneutics, potensi perempuan Amerika (tinjauan feminisme)

\section{INTRODUCTION}

Hermeneutics is a word relating to the compilation of theological, philosophical and interpretative texts such as literary texts. In its history, the term hermeneutics began to be used as a method in the interpretation of the biblical scriptures. The Third New International Dictionary in Webster, with the concept of hermeneutics is the study of methodological principles of interpretation and explanation; Special study of the general principles of biblical interpretation (Palmer, 2016:
4). This definition gives us an understanding that hermeneutics is a method or principles for finding meaning or intent of the author in a work (the Bible). However, in its development, the resolution of hermeneutics is not broad enough to meet the need for meaning so that other considerations arise related to the function and role of hermeneutics in some contexts and developments.

Malbon (1983: 212) said that there are three basic meanings of 
'hermpneuein' are: (1) to speak (or express or say), (2) to explain (or interpret or comment upon), (3) to translate. All three meanings may be expressed by the English verb 'to interpret,' yet each constitutes an independent and significant meaning of interpretation. There are three meanings of the word hermpneuein namely, speaking or expression, explaining, and translating. These three meanings refer to the English verb 'to interpretation'. But each is an independent and significant meaning of interpretation.

In its development, hermeneutics has expanded its meaning, including the definition of Recoer which states that hermeneutics is a transition between abstract reflection and concrete reflection (Puspoprodjo, 2015: 111). Boech (in Zuchdi and Afifah, 2019: 189) defines hermeneutics as the scientific methodology of the study of what is known already as a scientific method study of something that is already known. In contrast to Recoer and Boech, Schleiermacher (Palmer, 2016:
95), defines hermeneutics as the art of understanding, both to understand texts in the form of legal documents, religious books, and literary works. So that the definition of hermeneutics is divided into two groups, namely the specific definition and general definition. Special heremeneutics are produced by general hermeneutics. General hermeneutics depart from the formulation of all principles of language understanding, then the results are utilized by special hermeneutics. However, for Schleiermacher, the division is still not comprehensive enough so there is a more specific division, hermeneutics, philology, theology and law. Littlejohn and Fross in (Sobur, 2014: 241) state that there are three branches of hermeneutics, namely interpretation of the gospel (explanation), interpretation of literary texts (philology), and interpretation of human action (social hermeneutics).

Palmer (2016: 95) explains that hermeneutics is a source of theory that serves as a support for the tasks of translators when they begin to interact 
with the original text. In this case, the theory in question is not partial, but has been collected in a continuous element and will be an important spirit during the meaning of the text. Hermeneutics as an art of understanding also automatically acts as an art of listening. This means that hermeneutics rests on a general statement of how all utterances can be understood. The situation or state of mind arising from the studied text will certainly be part of a dialogic relationship. Then each relation will bring up a speaker whose role is to construct a sentence or unity of speech to represent the thoughts and feelings of the listener. The listener's position is the recipient of a series of words through an unexplained process. This process is called an unclear process because it is full of secrets and does not give a sign. Schleiermacher called it a hunch that was included in the study of hermeneutics (Palmer, 2016: 97).

Zuchdi and Afifah (2019: 200), stated that hermeneutics as a science of interpretation in its development is at least divided into two periods, the classical period with theological object of study and the contemporary period with broad and general object of study not only religious texts but social texts, culture and communication. In this paper, the writer tried to link this hermeneutic view in a book entitled "Potensi perempuan Amerika (tinjauan feminisme)" by Prof. Dr. Juliasih Kusharyanto. There are several reasons underlying the selection of the object of study, including the basic assumptions that form the basis of analysis in the book and the models that are applied more strongly towards hermeneutics, namely the reading of literary texts through various related sources so that conclusions obtained through analysis is the result of the meaning of various sources of the text.

\section{DISCUSSION}

\section{Wilhelm Dilthey}

Wilhelm Dilthey (1833 - 1933), born in the German city of Biebrich. Before studying philosophy, he had studied theology at the University of Heidelberg. Dilthey and Schleiermacher are the two main figures in developing objective hermeneutics or often also called 
intentional hermeneutic. Basically, Dilthey's hermeneutics are almost the same style as the hermeneutics developed by Schleiermacher, which are both based on the view that the text must be understood in accordance with what is described by the author. Therefore, they are both categorized as objective heremeneutics. What is called meaning or interpretation is not based on our conclusions as interpreters but the meaning and interpretation are derived and are instructive from the author.

There are three important elements that have an important role in hermeneutics, namely the attitude of understanding (verstehen) actions and events, the appreciation of the human mind (erlebnis), expression (ausdruck) of individual and social human life with historical approaches. The key word for Dilthey's geisteswissenschaften is understanding. Explanation is the property of science, but the approach to the phenomenon that unites the elements of nature and external elements is understanding. Science explains nature, humanity understands the expression of life.

In understanding the text, Dilthey assumed that the meaning of the text must be traced from the subjective intent of the author. For Dilthey, hermeneutics is "a technique of understanding expressions about life arranged in written form". Therefore, he emphasizes historical events and works which are expressions of past life experiences. To understand this experience, interpreters must have intense of the equality of perception with the author. Dilthey holds that such assumptions are historical. $\mathrm{He}$ considers the external influence in the development of the author's mind.

So, an understanding of literary texts, both those that developed in the past and the present will be better if you use the method of living life experiences contained in it. Humans understand themselves through the mediator of history as a process of understanding and interpreting that never stops. As in a text, life can grow and develop based on the merging of our experience with the experience of 
the text based on the merging of the past with the present because the past has a continuous relationship with the present.

How we understand a roman like Kuantar ke Gerbang of Ramadhan KH, or a literary work of the Earth of Man by Pramoedya Ananta Toer or other classical works such as Charles Dickens, Thomas Hardy, Shakespeare, and so on, all can only be done by dialogue with them to find out what the author intends. Even after a few hundred years or a few centuries ago, we can still understand the stories in the novel. These novels certainly have meaning and meaning can only be understood if we as readers are actively involved and immerse ourselves in the inner experiences experienced by the author. Reading is not enough to produce subtle meanings in text. We must compare with other matters related to the text and dive into the author's experience through existing histories.

Hadi (2008: 92) states that the core of Dilthey's hermeneutics includes the concept of a triangle, namely, Erlebnis (living experience), Ausdruck (expression), and Verstehen (understanding). The first concept in Dilthey's theory is Erlebnis (living experience). The word Erlebnis comes from the verb erleben which means "to experience". Erlebnis (living experience) involves the living and contemplation of life experienced by humans in certain historical periods in the midst of certain people's lives, with certain cultures as well, is a psychological process. Thus, research on these expressions involves an understanding of the psychiatric process that is assumed to accompany the birth of cultural expressions (Hadi, 2008: 69).

Erlebnis is a term used by Dilthey to refer to life experiences. What is meant by experience here is not something that we have experienced. $\mathrm{He}$ is not a recording of the past before us as the object of research. Experience, for Dilthey (Hadi, 2008: 69), is also not something that is produced through reflection and so on. The experience in question is the experience of life, where someone is in direct contact with 
reality. Whether it's dealing directly or through a transposition process, where someone will find himself in someone else. Life experience involves the appreciation and contemplation of life experienced by humans in certain historical periods in the middle of certain people's lives, with certain cultures as well, is a psychological process. Thus, research on these expressions involves understanding the psychiatric process that is assumed to accompany the birth of cultural expressions. According to Howard (2001: 164), experience has two meanings, namely immediacy and totality. Immediacy shows that meaning is present without the need for rationalization. Totality means that the content of meaning has a weight and is significant enough to integrate several moments in one's life. Experience in this regard is seen as a historical source

Ausdruck (expression) can be translated as "expression". The use of this concept does not have to automatically associate Dilthey with the theory of artistic expression, because the theory is formed in the subject-object concept. For Dilthey, an expression is not primarily the formation of one's feelings but rather an "expression of life", everything that reflects the product of life in humans (Palmer, 2016: 125-126).

For Dilthey, understanding a literary work can be understood by understanding the expressions of the author of the literary work. This understanding process follows the same logic as one understands activities in one's own autobiography. Autobiography is the best tool in understanding life and events in our lives. In other words, the expression is an objectification of relations or coherence in Erlebnis.

The last concept of Dilthey's hermeneutics is Verstehen (understanding). Verstehen as a separate approach for humans is important, because the human world contains meaning which in the physical world is not as similar as. In addition to being bound to consciousness, human activities are also driven by goals and arise from the interpretation of situations and appreciation of values. 
Next is how can be found "meaning" through the Verstehen process (Priyanto, 2001: 125-126). Verstehen is a word that can be compared to Erklaren which means to explain. The word Erklaren is usually used for something that is certain, very suitable for Naturwissenschaften. Verstehen is a process of understanding that is not only cognitive, but also includes the complexity of a human being. This understanding is also interpreted in a different meaning, namely understanding the expression in life experiences. The difference between Verstehen's and Erklaren's objects also affects the results of both.

$$
\text { Palmer (2016: 134-135) }
$$

explains that meaning has an important role in understanding. The meaning is what is gained experience in reciprocal interactions that are essential from the whole and the parts of the hermeneutical circle. a "meaning" obtained in the meaning of individual parts. An event or experience will change our lives, where what was previously meaningful becomes meaningless and vice versa. The meaning is something that is historical, it is an overall relationship to the parts that we see from a certain point of view, at certain times, for a combination of certain parts. The meaning changes over time, it is a matter of the relationship in which the event is seen. Thus, meaning is contextual and is part of the situation

\section{Hermeneutics and Literature}

In the study of socio-cultural sciences, the world of life cannot be approached by scientific methods such as the natural sciences. In natural knowledge, humans perceive phenomena that are different from themselves, whereas in historicalcultural knowledge, humans understand themselves. Therefore, a social scientist must enter the world of elements that he wants to explain. To explain, he needs to understand, and to understand, he must be able to participate in the processes that produce the living world. Finally, participation presupposes that he has entered into the living world. 
Sobur (2014: 245) explains that one of Dilthey's thoughts is a hermeneutic model that is able to break through the cultural distance between a hermeneur and the 'past world' of the text he wants to understand by producing various events lived by the writer or author of the text. The presupposition that underlies this hermeneutic is the ability to make 'historical transposition', that is, it can be separated from the context and entered into the author's historical situation.

According to Zayd (2003: 50), Dilthey emphasizes that the foundations of heremeneutic theory can explain general theories in understanding because after all the building of the internal world can be found based on interpretations of literary works, in which the sequence or woven of inner life reaches its most perfect form in these works. Therefore, hermeneutics is an attempt to understand experiences as contained in literary works, which often appear in the form of language and transform experiences from a frame of subjectivity to objectivity.

In each period, we can understand the past with new understanding, and understanding of the past will be better if the various conditions of objectivity contained in the present are the same as those in the past. Our understanding of texts of literary works, both of those developed in the past or those that have evolved in the present, with the method of living life experiences contained in them, will provide a better understanding of the past and the present simultaneously. In a text, life can grow and develop based on the merging of our experience with the experience of the text based on the merging of the past with the present. This can happen because the past has a continuous existence in the present, and the present can discover the past through its subjective experience.

Sobur (2014: 247) explains that in appreciating literary works, we start from our subjective experiences in certain historical events. Subjective experience will limit the meaning that we can understand from a work that 
also exists in a certain time. But our experience will change and gain a new dimension through the new horizons that appear in the text to us, and the next time our experience will really change because our understanding of the work also changes. Meaning can be different forms, however, it is always a form of cohesion, connectedness or related power, it is in a context.

Words, phrases, sentences, paragraphs, chapters, and the whole story in a literary work constitute a unified discourse that can be interpreted appropriately from each of the whole depending on the overall logical structure and its scientific, polemical, oratoric purpose and so on. Literary work is a unit of discourse which its meaning also depends on logical structure or relations between the structures that build it. Literary work, whatever its form, is essentially a view of ideas, ideas, or experiences of the author. With this work the author intends that the reading community also feels what he is experiencing. Literary works can be appreciated or researched.
The problem is how we appreciate or research the literary work.

Literary work is a description of life as a result of literary observations of life, about life in literary works is artificial life or fiction of the author who usually tells a human story with various problems of life and broad and complex life. Literary works are sourced from the facts that live in society (objective reality) but life in that society is not merely an imitation of nature or an imitation of life. Therefore, understanding literary works is impossible to forget the historical background that builds the life process in the story. Literary work is not a mere writing technique, but it has a set of facts to convey. But the understanding of the facts must be traced with the right method so that the interpretation is also right as close as possible. Hermeneutika offers a method for the interpretation of literary works.

\section{Dilthey's Hermeneuites Concept in Potensi Perempuan Amerika (Tinjauan Feminisme) by Juliasih Kusharyanto}


The book entitles Potensi Perempuan Amerika (Tinjauan Feminisme) by Juliasih Kusharyanto is a part of her disertation entitled "Potensi Perempuan Amerika dalam Novel Penulis Perempuan Amerika". The purpose of the book are to show the image of women and reveals the injustices experienced by women in four works of American women the awakening by Kate Chopin (1899), $O$ Pioners! by Willa Chater (1913), The Age of Innocence by Edith Wharton (1920), and Vein of Iron by Ellen Glasgow (1935). To describe everything related to injustice based on the question of what, who, why, how, and where the injustice occurs, and to show if there is injustice, it is necessary to examine whether injustice is taken for granted or there is a process awareness of the image of women in literary works, including discussing the extent to which the process of awareness is understood, and then actualized by these women.

In other words, how do they actualize the potential or abilities and strengths that exist in themselves, but have not been explored and brought to the surface. Actualization is a concrete manifestation of the capacity of women in work that occupies a strategic position as a messenger, mandate, moral, or something that the writer intends to convey as part of a social group (Kusharyanto, 2009: 17).

\subsection{Erlebnis in Potensi Perempuan Amerika (Tinjauan Feminisme) by Juliasih Kusharyanto}

As explained earlier, Erlebnis is a living experience that involves living and reflecting on the life experienced by humans in a certain historical period in the middle of a certain society, with a certain culture. The first thing described in this book is a description of life experiences experienced by American women in a certain period according to the year in which the novels were first published. The objects of research in this book are 4 American women's novels published in the mid 19th century until the early 20th century (1899-1935). 
According to Kusharyanto (p. 33), in 1850 to 1930 was a period of struggle in American history. In the words of the American female historian Cutter (1999), the period 1850 - 1930 was a time of voice problems in American culture, a transition from 'real women' to 'new women' (which) created major changes in women's identities and voices (p. 33). Furthermore, Cutter (Kusharyanto, p. 34) explains that women's literary works not only reflect, but also shape the role transition. This means that literary works have the power of sound in contributing American social culture.

In the next discussion (pp. 37-48), this book describes the situation of american women and their role in social life from the colonial period (1600-1760) to the industrialization period (1800s). During the colonial period, american women had a variety of roles, especially domestic roles such as being a housewife, partners in helping husbands in farming, volunteering (helping each other's neighbors), nurses (able to treat sick people or caring for sick families). In this colonial period, american women were very poorly educated, only a few received formal education and even then, only happened to women who came from Europe with middle and upper social class backgrounds.

Furthermore, the discussion is carried out by describing the history of american women during the American revolution (pp. 49-68). At this time, american women were divided into two groups: lower-class women and upper middle-class women. Lower-class women play the role of laborers who receive improper salaries. While the middle class and above are women who have the title 'lady'. The role of women in the middleclass and above remains in the domestic sphere, namely taking care of the house and family, her 
life depends on her husband who is economically established and has a business and trade. A lady is a woman who is at home behaving properly, serving a husband, taking care of children and all things relating to feminine matters. At this time american women also had the opportunity to work as teachers, although with half the salary of male teachers, women at that time became independent and were able to have a business by opening courses specifically for women.

American women's movements began during this revolution, such as religious social movements, anti-slavery movements, and missionary movements (pp. 98-107), movements to have voting rights (pp. 112-132), and feminism in America (p. 132 - 168).

Detailed description of the history of American women from the colonial period to the industrialization period was taken by Juliasih Kusharyanto from various historical sources such as a book by Carrol Hymowitz and Michael Weisman (1978) titled "A History of Women in America", Marylynn Salmon (2000) titled "The Limits of Independence : 1760 - 1800 ", Virginia Sapiro (1986) with the title" Women in American Society ", Martha J. Cutter (1999) titled" Untrully Tongue, Identity and Voice in American Women's Writing 1850 - 1930 ", and related other books. This is the way how Juliasih Kusharyanto brought to life the experiences of human life in certain periods related to her research. The writings of historian Henry Bamford Parker (1953) provide an outline of the socio-cultural conditions of America ranging from an agrarian country to the entry of technology and into an industrial state. From these writings, it can be traced how the life of American society in the transition 
from agrarian to industrial country.

Furthermore, to complement the Erlebnis of Dilthey concept, this book describes the autobiographies of 4 authors of the novels studied. The first autobiography was Kate Choplin (pp. 203 - 209), followed by Edith Wharton (pp. 209 - 215), then the autobiography of Willa Chather (pp. 215 - 219) and finally Ellen Glasgow (pp. 220 224). In this autobiography, Kusharyanto explained about the author's genealogy, written history and views and life experiences experienced during the novel's author lives that influenced the works their created. As explained on page 22, it is stated here that in order to analyze the works of the four female writers, an understanding of the writer's life setting, place, and time is required because literary works are the result of human culture that cannot be understood in their entirety if the totality of people's lives giving birth to the work was ignored. Quoting Junus (p. 22), the writer speaks as a spokesperson in his class determined by their social situation as a human, and that situation is reflected in their art. Regarding the biographies of the 4 writers, Kusharyanto (p. 22) took from various sources such as a book entitled Anthology of American Literature by Goerge McMichael (1980), Notable American Women 1607 - 1950 by Edward T. James et al. (1974), and The Oxford Companion to American Literature by James D. Hart (1965). Through these books the order of the writers' years of life, their philosophies, views, and concepts about life were obtained.

\subsection{Ausdruck in Potensi Perempuan Amerika (Tinjauan Feminisme) by Juliasih Kusharyanto} Ausdruck (expression) in Dilthey's hermeneutics is as one 
step towards understanding, because the expression itself is all the things that empirically give the main points of the humanities. The things that cover it include the communication of words that give birth to intentions, feelings, and deeds.

In research conducted by Juliasih Kusharyanto, Ausdrck or the analyzed phrases are expressions in the 4 novels (can be dialogues or narratives in stories in the novel) that have to do with the research objectives, namely those that describe the image of women and the injustices experienced by women. clues as to what, who, why, how, and where these injustices occur and expressions that indicate whether injustice is taken for granted or there is a process of awareness of the image of women in literary works, including discussing the extent of the process of awareness it is understood, and then actualized by these women. For example, in a phrase that shows that American women are smart women but do not have the opportunity to develop themselves because women will only become a housewife. In the novel The Awakening, for example, the character Edna is an intelligent woman and likes to discuss everything, including politics and religion

Her most intimate friend at school had been one of rather exceptional intellectual gifts, who wrote fine-sounding essays, which Edna admired and strove to imitate; and with her she talked and glowed over the English classics, and sometimes held religious and political controversies. (Chopin, 1976:18)

Through expressions like the example above, it can be understood that in the novels studied there are certain purposes to be conveyed by the writer. The author uses the story as a medium to voice the desires that actually want to be achieved in the fabric 
of social life. The character's expressions in the novel's story are used as a communication tool so that the reader knows the intentions, feelings, and deeds of the writer.

\subsection{Verstehen in Potensi Perempuan Amerika (tinjauan feminisme) by Juliasih Kusharyanto}

Verstehen as explained in the previous discussion above is an understanding process that basically combines two processes namely Erlebnis and Ausdruck. Combining these two processes is expected to be able to provide an understanding of the meaning that is in the text. The research "Potensi Perempuan Amerika (Tinjauan Feminisme)" ultimately produced the meanings contained in the 4 novels studied. Through the process of reading Dithley's hermeneutics, Juliasih Kusharyanto was able to provide a comprehensive explanation of the meanings in the novels. The resulting meaning succeeded in answering research questions both in terms of American history, the author of the novel, and related expressions through the stories and actions of the characters in the novel.

For example, in interpreting the intent of The Awakening by Kate Choplin. Through historical facts, Kusharyanto managed to explain the environment and life experience behind Kate Choplin writing the novel. Choplin, who was born in the era of america Industrialization, experienced various events specifically related to the social norms of women at that time. A lot of discrimination and injustice happens to women. Therefore, The Awakening novel voiced women's interests. Through expressions, language, dialogue, and the actions of the characters in the novel, Choplin fought for the fate of women and fought injustice. In the novel The 
Awakening, there are many narratives and actions that underline the marginalization of women even though women have the extraordinary potential to be equal to men. In fact, in the autobigraphy written by Kusharyanto (p. 204), it was stated that the novel The Awakening was withdrawn from circulation and the library because its contents were considered to be in conflict with the norms of the society at that time. While Chopin himself was exiled by the public, including her friends. The Awakening told of a woman who follows her heart and does not hesitate to leave her child and husband because of having an affair with another man. Because of this, the book was considered a 'poison' that endangered the mindset of the people, especially women at that time.

Three other novels studied also provide meaning similar to the novel The Awakening. All stories illustrate that american women have the potential to be independent, advanced, intellectual, and able to become leaders. However, the patriarchal system which at that time ruled America did not provide a loophole for women to develop these potentials. This is in accordance with social facts that occurred in America at that time. In the novel The Age of Innocence by Edith Warton, Kusharyanto gives the meaning that because Edith Warton lived in the midst of the industrial revolution, her works depict much of New York society in the twentieth century. At that time, New York society had turned into an industrial society. The development of the industry made the city of New York experience rapid development and as a result many emigrants came and settled there. These changes are described in many of her works. Warthon does not seem to like the changes in the 
traditional values of the old society changing with the modern society which she thinks is a greedy, rude and money-oriented society. In The Age of Innocence, Wharton illustrated that innocence, manners are only bound to the surface, different from the actual situation so that what arises is the attitude of hypocrisy and arrogance.

$O$ Pioneers! is a classic novel by Willa Cather, about the lives of the inhabitants of the Nebraska prairie, O Pionner!, known for its vivid portrayals of the daily lives of Scandinavian immigrant pioneers. In his work, Willa Cather placed a woman as the main character, who has a strong nature, and is able to break out of culture in her environment. Alexandra Bergson, the main character in $O$ Pioneer!, is described as a tall and strong figure who often wears a man's coat, a round hat and a coat tied around her neck, covering part of his face. She was not bothered by her appearance, even though many people mocked her.

Alexandra Bergson lives with her husband and younger brother. He loved her sister very much, and was willing to raise her. But it brought jealousy to her husband, so that the younger brother was killed. Over the years, Alexandra suffered greatly after her beloved brother was killed by the person she married. Willa Cather was able to invite her readers to share in the feelings of the main character, through excellent choice of words.

Willa Cather is also very good at presenting images of the life of the Nebraskan people who are at one with the natural environment. In this research, through the Dilthey's hermeneutic process, this novel is interpreted as a novel that voiced Cather's desire as a woman living within the limitations of the american version of the Victorian Era. In her autobigraphy, Cather is described as a woman who has 
a male style with a short whip and likes to wear male-style clothes. Quoting O'Connor (Kusharyanto, 2009: 217), Cather's rebellion against conventional dress and behavior became a sign of firmness that gave Cather the confidence to achieve success in a culture that still strongly restrained women who could not accept the roles assigned to her based on that culture. This is also reflected in the character of Alexandra Bergson in Novel $O$ Pioneer!, as contained in the following narrative.

"His sister was a tall, strong gril, and she walked rapidly and resolutely, as if she knew exactly where she was going and what she was going to do next" ( $\mathrm{p}$. 6).

Beside being physically male, Alexandra was also described as happy wearing a man's clothes as did the author of the novel.

She wore a man's long ulster (not as if it were an affiction, but as if it were very comfortable and belonged to her; carried it like a young soldier), and a round plush cap, tied down with a thick veil (pl. 6).

Another image of Alexandria is described as the following narrative.
'Her figure is fuller, and she has more color. She seems sunnier and more vigorous than she did as a young girl. Her face is always tanned in summer, for her sunbonnet is oftener on her arm than on her head. But where her collar falls away from her neck, or where her sleeves are pushed back from her wrist, the skin is of such smoothness and whiteness as none but Swedish women ever possess; skin with of snow itself (p. 88).

All the discussion above are the hermeneutical contributions in the meaning of the 4 novels studied in the book. Hermeneutics provides a way for researchers to 'break through' nature of literary writers through history. Through a historical approach, researchers are able to present facts in the past through records or historical 
sources related to the literary work. Researchers are also able to be directly involved with the life experience of literary writers through autobigraphy. Hermeneutics offers a way to explore the facts that exist in the text of literary works through a process that is passed through the mediation of history as a process of understanding and interpreting that never stops. Humans experience change, progress, and become moderate. Like a text, life can grow and develop based on the merging of our experience with the experience of the text based on the merging of the past and the present, so we end up circling in the heremeneutic circle. Third, through relations between the hermeneutic elements (hermeneutic circle), humans can provide a comprehensive conclusion so that the meanings obtained are the result of interpretations between experiences that lived in the past, reality of the past and present.

\section{CONCLUSION}

According to hermeneutics, humans are not merely language creatures, but existential beings. Since the beginning man has never lived only as a linguistic creature who only listens, writes and reads to later understand and interpret. More than that, humans are beings who understand and interpret in every aspect of their lives.

In understanding and interpreting meaning, there are 3 formulas that can be used as interpretive methods, namely Erlebnis (living experience), Ausdruck (expression), and Verstehen (understanding). The experience referred to here is the life history of the author, everything that was experienced by the director during his lifetime. The expressions are works written by the author through the language used to voice their desires, opinions and actions. Understanding is the process of bringing together all the data generated from the process of experience and expression so that it can draw conclusions. In the research conducted by Juliasih Kusharyanto, it can be 
concluded that the three main aspects of the hermeneutics have been carried out well so that in the end the results of the research are able to provide a complete meaning from the historical side as well as language expressions that exist in the storyline of each novel studied.

\section{REFERENCE}

Ahimsa-Putra, H. S. 2009. Paradigma Ilmu Sosial-Budaya-Sebuah Pandangan-. Makalah Kuliah Umum Paradigma Penelitian Ilmu-Ilmu Humaniora. Pascasarjana Universitas Pendidikan Indonesia, Tidak diterbitkan.

Hadi, A. 2008. Hermeneutika Sastra Barat dan Timur. Jakarta: Depdiknas.

Hardiman, F. B. 2015. Seni Memahami: Hermeneutika dari Schleiermacher sampai Derrida. Yogyakarta: PT. Kanisius.

Howard, R. J. 2001. Hermeneutika terj. Kusmana, Bandung: Penerbit Nuansa.

Kusharyanto, J. 2009. Potensi Perempuan Amerika (Tinjauan Feminisme). Yogyakarta: Gadjah Mada University Press.

Malbon, E. S. Structuralism, Hermeneutics, and Contextual Meaning Source: Journal of the American Academy of Religion, Vol. 51, No. 2 (Jun., 1983), pp. 207230 Published by: Oxford University Press

Palmer, E. R. 2016. Hermeneutics Interpretation Theory in Schleirmacher, Dilthey, Heidegger, and Gadamer. (Terjemahan dalam bahasa Indonesia oleh Musnur Hery dan Damanhuri Muhammed) Hermeneutika Teori Baru Mengenai Interpretasi. Edisi III. Yogyakarta: Pustaka Pelajar.

Priyanto, S. 2001. Wilhelm Dilthey: Peletak Dasar Ilmu-Ilmu Humaniora. Semarang: Bendera.

Risman, A. 1981. Metodologi Humaniora Dilthey dalam Jurnal Al-Jami'ah No. 25, Yogyakarta: IAIN Sunan Kalijaga.

Sobur, A. 2014. Filsafat Komunikasi. Tradisi dan Metode Fenomenologi. Edisi kedua. Bandung: PT. Remaja Rosdikarya.

Sumaryono, E. 1993. Hermeneutik Sebuah Metode Filsalat. Yogyakarta: Kanisius.

Zuchdi, D. \& Afifah, W. 2019. Analisis Konten Etnografi \& Grounded Theory Research dan Hermeneutika dalam Penelitian. Jakarta: PT. Bumi Aksara. 